\title{
Angiotensin II contractile effects in mouse colon: role for pre- and post-junctional $A T_{I_{A}}$ receptors
}

\author{
M. Mastropaolo, M. G. Zizzo, F. Mulè and R. Serio \\ Dipartimento di Scienze e Tecnologie Molecolari e Biomolecolari (STEMBIO), Laboratorio di Fisiologia generale, Università di Palermo, Palermo, Italy
}

Received 6 July 2012 ,

revision requested 29 August

2012

revision received 14 November

2012

accepted 15 November 2012

Correspondence: Rosa Serio,

Dipartimento di Scienze e Tec-

nologie Molecolari e Biomoleco-

lari (STEMBIO), Laboratorio di

Fisiologia generale, Università di

Palermo, Viale delle Scienze,

90128 Palermo, Italy.

E-mail: rosa.serio@unipa.it

\begin{abstract}
Aim: This study investigates whether a local renin-angiotensin system (RAS) exists in mouse colon and whether angiotensin II (Ang II) may play a role in the regulation of the contractile activity.

Methods: Isometric recordings were performed in vitro on the longitudinal muscle of mouse proximal and distal colon. Transcripts encoding for RAS components were investigated by RT-PCR.

Results: Ang II caused, in both preparations, a concentration-dependent contractile effect, antagonized by losartan, $\mathrm{AT}_{1}$ receptor antagonist, but not by PD123319, $\mathrm{AT}_{2}$ receptor antagonist. The combination of losartan plus PD123319 caused no change on the Ang II-induced contraction than losartan alone. Tetrodotoxin, neural blocker, reduced the contractile response to Ang II in the proximal colon, whilst the response was abolished in the distal colon. In both preparations, atropine, muscarinic receptor antagonist, or SR140333, $\mathrm{NK}_{1}$ receptor antagonist, reduced the Ang II responses. Ondansetron, 5- $\mathrm{HT}_{3}$ receptor antagonist, SR48968, $\mathrm{NK}_{2}$ receptor antagonist, or hexamethonium, nicotinic receptor antagonist, were ineffective. The joint application of atropine and SR140333 produced no additive effect. Atropine reduced $\mathrm{NK}_{1}$-induced contraction. Transcripts encoding RAS components were detected in the colon samples. However, just $\mathrm{AT}_{1 \mathrm{~A}}$ mRNA was expressed in both preparations, and $\mathrm{AT}_{2}$ mRNA was expressed only in the distal colon.

Conclusion: In the murine colon, local RAS may play a significant role in the control of contractile activity. Ang II positively modulates the spontaneous contractile activity via activation of post-junctional and pre-junctional $\mathrm{AT}_{1 \mathrm{~A}}$ receptors, the latter located on the enteric neurones, modulating the release of tachykinins and acetylcholine.

Keywords angiotensin II, $\mathrm{AT}_{1}$ receptors, $\mathrm{AT}_{2}$ receptors, enteric neurones, mouse colon, muscle contraction.
\end{abstract}

Angiotensin II (Ang II), the major bioactive component of the renin-angiotensin system (RAS), induces a multitude of events contributing to the regulation of blood pressure, body fluid volume and electrolyte balance. Traditionally, RAS is regarded as an endocrine system, but its components can be found in several tissues, indicating also paracrine-autocrine functions (Paul et al. 2006, Fyhrquist \& Saijonmaa 2008). Two main Ang II receptors have been described, namely $\mathrm{AT}_{1}$ and $\mathrm{AT}_{2}$, receptors, both members of the Gprotein-coupled receptor family (De Gasparo et al. 2000). The rat and mouse $\mathrm{AT}_{1}$ receptors exist as two 
distinct subtypes, termed $\mathrm{AT}_{1 \mathrm{~A}}$ and $\mathrm{AT}_{1 \mathrm{~B}}$, which are $95 \%$ identical in their amino acid sequences. The two subtypes are also similar in terms of their ligand binding and activation properties but differ in their tissue distribution, chromosomal localization, genomic structure and transcriptional regulation (De Gasparo et al. 2000). The $\mathrm{AT}_{1}$ receptor mediates all classical actions of Ang II in cardiovascular, renal, neuronal, endocrine, hepatic and other target cells. These actions contribute to the maintenance of arterial blood pressure, electrolyte and water balance, thirst, renal function and structural remodelling of cardiovascular tissue (De Gasparo et al. 2000, Jackson 2001). $\mathrm{AT}_{2}$ receptors, on the other hand, have been suggested to counterbalance most effects that Ang II exerts through the $\mathrm{AT}_{1}$ receptors (Volpe et al. 2003).

Compared to the cardiovascular, renal and central nervous systems, there are only few studies on the role of RAS in the gastrointestinal tract, although intestinal smooth muscle, ion and fluid transporting epithelia and host defence cells, all have the potential to be targets for RAS-mediated regulation. The presence of Ang II receptors at various levels along the GI tract has been demonstrated in human, guinea-pig and rat (Wang et al. 2005, Ewert et al. 2006, Spak et al. 2008), suggesting a potential physiological action. In particular, Ang II has been reported to regulate intestinal fluid and electrolyte transport (Fändriks 2010, 2011). Because intestinal motility has consequent impact on intestinal transit (Nylander 2011), the possibility that Ang II would modulate contractility can be suggested. Indeed, early studies have shown that Ang II induces contractile responses in the longitudinal muscle of guinea-pig small intestine, via activation of neural $\mathrm{AT}_{1}$ receptor, which mediates the release of acetylcholine and substance $\mathrm{P}$, and $\mathrm{AT}_{1}$ receptor located on smooth muscle cells (Hawcock \& Barnes 1993). Subsequently, the expression of $\mathrm{AT}_{1}$ receptor protein and the mRNA transcript for $\mathrm{AT}_{1}$ receptors in the guinea-pig enteric nervous system has been confirmed (Wang et al. 2005). Indeed, Ang II-induced contractions primarily mediated through $\mathrm{AT}_{1}$ receptors located on the musculature have been pharmacologically characterized in isolated human and rat small intestine (Ewert et al. 2006, Spak et al. 2008) and in human oesophagus (Casselbrant et al. 2007).

Thus, in consideration that the role of Ang II in the bowel motility is far from being clear, the aim of this study was to pharmacologically analyse the effects of Ang II on mouse proximal and distal colon contractility, to characterize the subtype(s) of receptor(s) involved and to investigate the action mechanism. Moreover, the eventual existence of a local RAS in mouse colon was investigated by RT-PCR.

\section{Materials and methods}

\section{Animals}

The study is conforming to Good Publishing Practice in Physiology (Persson \& Henriksson 2011). Experiments were performed on adult male mice (C57BL/ 10SnJ; weighing $25.5 \pm 0.5$ g; Charles River Laboratories, Calco-Lecco, Italy). Animals were killed by cervical dislocation, and after a midline laparotomy, the entire colon was removed (about $15 \mathrm{~cm}$ length) and placed in Krebs solution (in mM: $\mathrm{NaCl} 119 ; \mathrm{KCl}$ 4.5; $\mathrm{MgSO}_{4} 2.5 ; \mathrm{NaHCO}_{3} 25 ; \mathrm{KH}_{2} \mathrm{PO}_{4} 1.2, \mathrm{CaCl}_{2}$ 2.5, glucose 11.1).

\section{Recording of mechanical activity}

Mechanical activity of isolated intestinal segments was recorded as previously described (Zizzo et al. 2006, Baldassano et al. 2009). This experimental approach was chosen to study the muscle function under conditions where the influence of external factors is removed, but the muscle itself performs in a manner analogous to its in vivo capacity. Briefly, longitudinally oriented segments (about $20 \mathrm{~mm}$ in length) from proximal (immediately distal to the caecum) or distal (about $5 \mathrm{~mm}$ proximal to the anus) colon were suspended in a $10-\mathrm{mL}$ organ bath wells with oxygenated $\left(95 \% \mathrm{O}_{2}\right.$ and $\left.5 \% \mathrm{CO}_{2}\right)$ Krebs solution $\left(37^{\circ} \mathrm{C}\right)$, anchored at the distal end to an organ holder and at the proximal end secured with a silk thread to a force transducer (FORT 10, Ugo Basile, Biological Research Apparatus, Comerio VA, Italy) for isometric recording of muscular activity (PowerLab/400 system, Ugo Basile, Italy). Preparations, $200 \mathrm{mg}$ preloaded, were allowed to equilibrate for at least $30 \mathrm{~min}$ to develop rhythmic spontaneous contractions. Then, preparations were challenged with $0.1 \mu \mathrm{M}$ isoproterenol or with $10 \mu \mathrm{m}$ carbachol (CCh) until stable responses were obtained. The amplitude of the relaxation induced by isoproterenol in proximal colon was $0.19 \pm 0.04 \mathrm{~g}(n=48)$ and in distal colon was $0.23 \pm 0.07 \mathrm{~g} \quad(n=48)$. The contractile response to $\mathrm{CCh}$ in proximal colon was $1.35 \pm 0.12 \mathrm{~g}(n=48)$ and in distal colon was $1.32 \pm 0.19 \mathrm{~g}(n=48)$.

Non-cumulative concentration-response curves for Ang II, in the absence or in the presence of AT receptor antagonists, were constructed by addition of Ang II for approximately $5 \mathrm{~min}$ at 1 -h intervals.

In a second set of experiments, a submaximal dose of Ang II (1 nM) was used to determine the effects of tetrodotoxin (TTX), atropine, hexamethonium, ondasetron, SR 140333 and SR48968. 


\section{Solution and drugs}

Drugs used were atropine sulphate, carbamylcholine chloride (carbachol, CCh), hexamethonium bromide, isoproterenol, ondansetron hydrochloride dehydrate and TTX from Sigma-Aldrich Inc. (St Louis, MO, USA); angiotensin II, 1-[[4-(Dimethylamino)-3-methylphenyl] methyl]-5-(diphenylacetyl)-4,5,6,7-tetrahydro-1H-imidazo[4,5-c] pyridine-6-carboxylic acid ditrifluoroacetate (PD123319) and 2-Butyl-4-chloro-1-[[2'-(1Htetrazol-5-yl)-[1,1'-biphenyl]-4-yl]methyl]-1H-imidazole-5-methanol potassium salt (losartan) from Tocris Bioscience (Bristol, UK); (S)-N-methyl-N[4-(4-acetylamino-4-phenylpiperi-dino)-2-(3,4-dichloro-phenyl) butyl] benzamide (SR48968) and (S)-1-[2-[3-(3,4-dichlorphenyl)-1 (3-isopropoxy-phenylacetyl) piperidin-3yl] ethyl]-4-phenyl-1 azaniabicyclo[2.2.2] octane chloride (SR140333) were gifts from Sanofi Recherche (Montpellier Cédex, France); [Sar ${ }^{9}$, Met $\left.\left(\mathrm{O}_{2}\right)^{11}\right]$-substance P was from Calbiochem-Novabiochem (Laufelfingen, Switzerland). SR48968 and SR140333 were dissolved in dimethyl sulphoxide ( $0.1 \%$ final concentration), and $\left[\mathrm{Sar}^{9}\right.$, Met $\left.\left(\mathrm{O}_{2}\right)^{11}\right]$-substance P was dissolved in diluted acetic acid. All the other drugs were dissolved in distilled water. Working solutions were then dissolved in Krebs solution.

\section{RNA preparation and RT-PCR analysis}

Total RNA was extracted from whole thickness proximal and distal colon, and cDNA was prepared as previously described (Zizzo et al. 2011). The oligonucleotide primers for amplification of cDNA (30 ng per reaction) encoding for angiotensin II type 1 subtype $\mathrm{A}$ and $\mathrm{B}$ receptors $\left(\mathrm{AT}_{1 \mathrm{~A}}, \mathrm{AT}_{1 \mathrm{~B}}\right)$, angiotensin II type 2 receptor (AT2), angiotensinogen (AGT), angiotensin-converting enzyme (ACE), renin and $\beta$-actin were designed from published mouse cDNA sequences and are summarized in Table 1. PCR analysis was performed in triplicate. Each PCR cycle consisted of denaturing at $94{ }^{\circ} \mathrm{C}$ for $45 \mathrm{~s}$, annealing at $56{ }^{\circ} \mathrm{C}\left(\mathrm{AT}_{1 \mathrm{~A}}\right.$ receptor, AGT and $\beta$-actin) for $60 \mathrm{~s}$ or at $48{ }^{\circ} \mathrm{C}\left(\mathrm{AT}_{1 \mathrm{~B}}\right.$ receptor and $\left.\mathrm{ACE}\right)$ for $45 \mathrm{~s}$ or $58^{\circ} \mathrm{C}$ (renin) for $45 \mathrm{~s}$ or $40{ }^{\circ} \mathrm{C}$ ( $\mathrm{AT}_{2}$ receptor) for $60 \mathrm{~s}$ and extension at $72{ }^{\circ} \mathrm{C}$ for $1 \mathrm{~min}$. This was repeated for 35 cycles, followed by extension at $72{ }^{\circ} \mathrm{C}$ for $15 \mathrm{~min}$. The amplimers were separated on a $1.8 \%$ agarose gel containing $0.5 \mu \mathrm{g} \mathrm{mL}^{-1}$ of GelStar Nucleic Acid Gel Stain (Lonza Rockland, ME USA) for visualization.

\section{Statistical analysis}

All data are presented as means \pm SEM: ' $n$ ' indicates the number of animal preparations. Contractile responses induced by Ang II were reported as a percentage of the effect induced by $10 \mu \mathrm{M}$ CCh. Ang II responses were fitted to sigmoid curves (Prism 4.0, Graph-PAD, San Diego, CA, USA), and $\mathrm{EC}_{50}$ values with $95 \%$ confidence limits (CLs) were determined. Antagonist potency was expressed as the negative logarithm of the concentration of the antagonist required to cause a twofold rightward shift of the agonist dose -response curve $\left(\mathrm{pA}_{2}\right.$ value), calculated by nonlinear regression analysis of the individual dose-response curves. Statistically significant differences were calculated by Student's $t$-test or by analysis of variance followed by Bonferroni's test. $P<0.05$ was considered statistically significant.

\section{Results}

\section{Intestinal muscle contractility in vitro}

Ang II (0.001-100 nM) induced, concentration dependently, a contractile effect in both preparations, with similar potency (proximal colon: $\mathrm{EC}_{50}$ : $0.08 \mathrm{nM}, 95 \%$

Table I Primer sequences for reverse transcription-polymerase chain reaction (RT-PCR)

\begin{tabular}{|c|c|c|}
\hline RAS component & Primer sequences & Fragment size \\
\hline Angiotensinogen (AGT) & $\begin{array}{l}\text { Forward: 5'-TATCCACTGACCCAGTTCTTT3'- } \\
\text { Reverse: 5'-AGTGAACGTAGGTGTTGAAA3'- }\end{array}$ & $133 \mathrm{bp}$ \\
\hline Renin & $\begin{array}{l}\text { Forward: 5'-ATGAAGGGGGTGTCTGTGGGGTC3'- } \\
\text { Reverse: 5'-ATGTCGGGGAGGGTGGGCACCTG3'- }\end{array}$ & 194 bp \\
\hline ACE & $\begin{array}{l}\text { Forward: 5'-CTGCGTAGAGGTGCCAACC3'- } \\
\text { Reverse: 5'-ACGGTGTCACGTTTGGGATG3'- }\end{array}$ & $357 \mathrm{bp}$ \\
\hline $\mathrm{AT}_{1 \mathrm{~A}}$ & $\begin{array}{l}\text { Forward: 5'-TCACCTGCATCATCATCTGG3'- } \\
\text { Reverse: 5'-AGCTGGTAAGAATGATTAGG3'- }\end{array}$ & 204 bp \\
\hline $\mathrm{AT}_{1 \mathrm{~B}}$ & $\begin{array}{l}\text { Forward: 5'-TGGCTTGGCTAGTTTGCCG3'- } \\
\text { Reverse: 5'-ACCCAGTCCAATGGGGAGT3'- }\end{array}$ & 121 bp \\
\hline $\mathrm{AT}_{2}$ & $\begin{array}{l}\text { Forward: 5'-TCCTTTTGATAATCTCAAC3'- } \\
\text { Reverse: 5'-CAAACACTTTGCACATCACA3'- }\end{array}$ & $310 \mathrm{bp}$ \\
\hline$\beta$-Actin & $\begin{array}{l}\text { Forward: 5'-CCGCCCTAGGCACCAGGGT3'- } \\
\text { Reverse: 5'-GGCTGGGGTGTTGAAGGTCTCAAA3'- }\end{array}$ & $300 \mathrm{bp}$ \\
\hline
\end{tabular}


Cls $\quad 0.03-0.23 \mathrm{nM}, \quad n=12$; distal colon: $\mathrm{EC}_{50}=0.05 \mathrm{nM}, \quad 95 \% \quad$ Cls $0.02-0.09 \mathrm{~nm}, \quad n=12$ ) (Fig. 1-3). At the dose of $10 \mathrm{~nm}$, the maximal response was observed, being in absolute values $958.5 \pm 15.0 \mathrm{mg} \quad(n=12) \quad$ in proximal and $765.5 \pm 18.2 \mathrm{mg}(n=12)$ in distal colon. An inhibitory/relaxant effect induced by Ang II was never observed, at any concentration tested. The responses to Ang II were antagonized in a concentration-dependent fashion $\left(\mathrm{pA}_{2}=9.8 \pm 0.05\right.$ and $\left.10.1 \pm 0.02\right)$ by losartan, $\mathrm{AT}_{1}$ receptor antagonist (Fig. 2), whilst PD123319 (up to $0.1 \mu \mathrm{M}$ ), $\mathrm{AT}_{2}$ receptor antagonist, was without any effect (Fig. 3). AT receptor antagonists had no effects on the spontaneous activity. The combination of losartan (10 nM) plus PD123319 $(0.1 \mu \mathrm{M})$ showed identical results to those of losartan alone (Fig. 3).

The neural toxin, TTX $(1 \mu \mathrm{M})$, reduced the contractile response to a submaximal dose of Ang II (1 nM) in the proximal colon, whilst abolished it in the distal colon (Fig. 4).

To characterize the neural pathway(s) mediating the indirect (TTX-sensitive) contractile effect induced by activation of $\mathrm{AT}_{1}$ receptors, Ang II was tested in the presence of antagonists for cholinergic, serotoninergic or tachykinergic receptors, the main excitatory system involved in the control gut motility. Atropine $(1 \mu \mathrm{M})$, muscarinic receptor antagonist, or SR140333
$(0.1 \mu \mathrm{M}), \quad \mathrm{NK}_{1}$ receptor antagonist, reduced the excitatory effects induced by Ang II (1 nM) in both proximal and distal colon (Fig. 4). On the contrary, ondansetron $(0.1 \mu \mathrm{M}), 5-\mathrm{HT}_{3}$ receptor antagonist, SR48968 $(0.1 \mu \mathrm{M}), \mathrm{NK}_{2}$ receptor antagonist, or hexamethonium $(30 \mu \mathrm{M})$, nicotinic receptor antagonist, were ineffective (Fig. 4). No differences were found in the effects induced by TTX, atropine and SR140333 on Ang II responses. Moreover, the combination of atropine $(1 \mu \mathrm{M})$ and SR $140333(0.1 \mu \mathrm{M})$ produced no additive effect (Fig. 4). None of the antagonists used had any significant influence on the spontaneous contractile activity.

Lastly, as shown in Fig. 5, atropine $(1 \mu \mathrm{M})$ significantly reduced the contraction evoked by a specific $\mathrm{NK}_{1}$ receptor agonist, [Sar $\left.{ }^{9}, \operatorname{Met}\left(\mathrm{O}_{2}\right)^{11}\right]$-substance P $(1 \mu \mathrm{M})$, whilst SR140333 $(0.1 \mu \mathrm{M})$ failed to affect the contraction evoked by CCh $(10 \mu \mathrm{M})$ in distal colon. Same results were obtained in the proximal colon.

\section{Transcripts encoding RAS components in proximal and distal colon}

Transcripts encoding renin, $\mathrm{AGT}, \mathrm{ACE}$ and $\mathrm{AT}_{1 \mathrm{~A}}$ receptors were found in the whole thickness preparations (Fig. 6). $\mathrm{AT}_{1 \mathrm{~B}}$ mRNA was not expressed in both preparations, whilst $\mathrm{AT}_{2}$ mRNA was expressed just in the distal colon (Fig. 6).
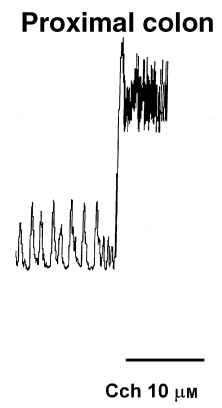

Distal colon

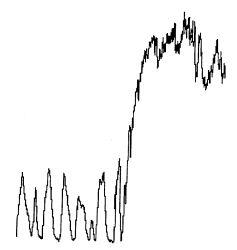

Cch $10 \mu \mathrm{m}$
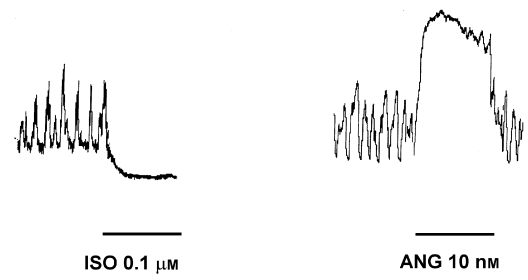

ANG $10 \mathrm{~nm}$

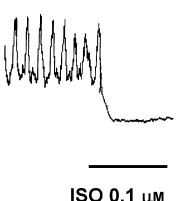

$$
\begin{aligned}
& 250 \mathrm{mg} \\
& \frac{1 \mathrm{~min}}{}
\end{aligned}
$$

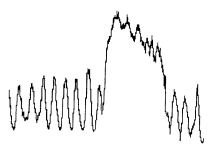

ANG $10 \mathrm{~nm}$

Figure I Original recordings showing the mechanical responses evoked by CCh, isoproterenol (ISO) or Ang II in mouse proximal and distal colon. 

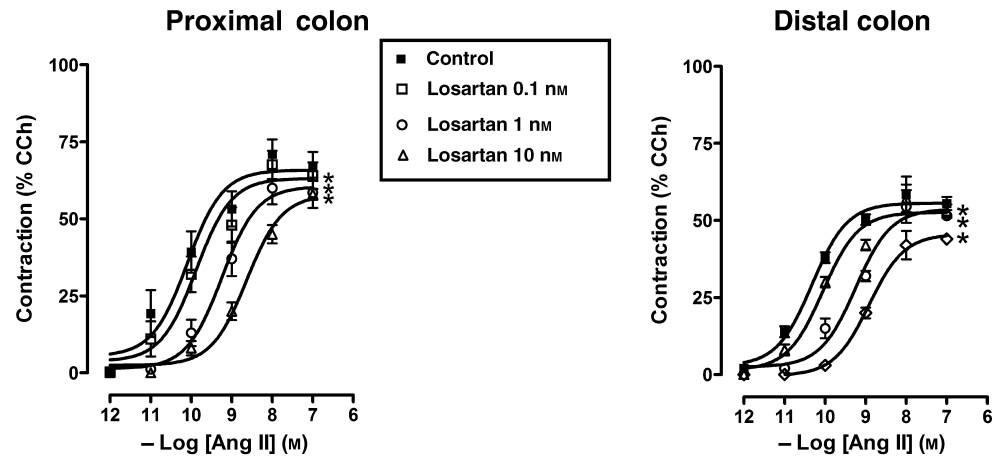

Figure 2 Concentration-response curves to Ang II before and after different concentrations of losartan, $\mathrm{AT}_{1}$ receptor antagonist $(n=4$ each), in mouse proximal and distal colon. Data are means \pm SEM and are expressed as percentage of the maximal effect induced by $10 \mu \mathrm{M}$ CCh. The values for the control curves are the means of the control data obtained before each treatment ( $n=12$ for both proximal and distal colon). ${ }^{*} P<0.05$ when the concentration-response curves were compared to those obtained in the respective control condition.
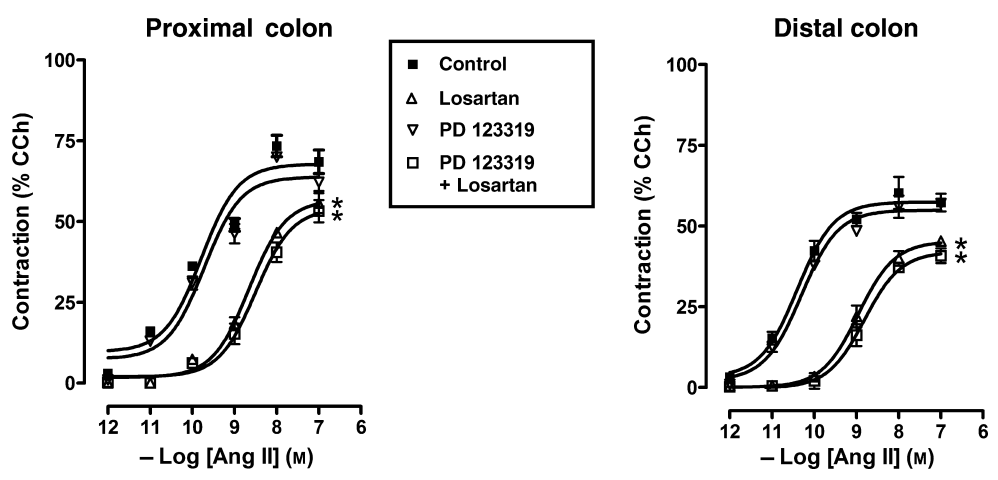

Figure 3 Concentration-response curves to Ang II before and after PD123319 (0.1 $\mu \mathrm{M}, n=3), \mathrm{AT}_{2}$ receptor antagonist, losar$\tan (10 \mathrm{nM}, n=3), \mathrm{AT}_{1}$ receptor antagonist or PD123319 plus losartan $(n=3)$ in mouse proximal and distal colon. Data are means \pm SEM and are expressed as percentage of the maximal effect induced by $10 \mu \mathrm{M} \mathrm{CCh}$. The values for the control curves are the means of the control data obtained before each treatment $\left(n=9\right.$ for both proximal and distal colon). ${ }^{*}<0.05$ when the concentration-response curves were compared to those obtained in the respective control condition.

\section{Discussion}

Ang II, the main effector peptide in the renin-Ang system (RAS), is known to elicit a wide range of diverse cellular responses, including growth, proliferation and vascular smooth muscle contraction. It has gradually become evident that in addition to the 'circulating RAS', there is also a 'local RAS' able to generate all bioactive Ang peptides in several tissues and organs, making RAS also a paracrine-autocrine system (Paul et al. 2006, Fyhrquist \& Saijonmaa 2008).

Ang II acts via cell surface receptors subdivided into $\mathrm{AT}_{1}$ or $\mathrm{AT}_{2}$ type, characterized using selective ligands (De Gasparo et al. 2000). In rodents, two isoforms of the $\mathrm{AT}_{1}$ receptor are expressed, termed $\mathrm{AT}_{1 \mathrm{~A}}$ and $\mathrm{AT}_{1 \mathrm{~B}} \cdot \mathrm{AT}_{1 \mathrm{~A}}$ receptors occur predominantly in vascular smooth muscle cells, liver, lung and kidney, whereas $\mathrm{AT}_{1 \mathrm{~B}}$ can be found mainly in adrenal and anterior pituitary (Johren et al. 2003). $\mathrm{AT}_{2}$ receptors are expressed at certain locations in the adult organisms such as in the adrenal gland, brain and myocardium as well as in the vasculature (Fyhrquist \& Saijonmaa 2008). Data from our experiments indicate that in mouse colon, a local RAS system exists supporting a local action played by Ang II (and its receptors) in the regulation of the gastrointestinal function. Moreover, evidence suggests that RAS dysfunction may potentiate immune-based diseases such as IBD, raising the possibility that local RAS system may become a potential therapeutic target in a various gastrointestinal diseases (Garg et al. 2012).

Thus, considering that the actions Ang II on gastrointestinal wall musculature have not been thoroughly investigated, we aimed to investigate whether or not Ang II could be considered a modulator of the spontaneous intestinal motor activity using as experimental 

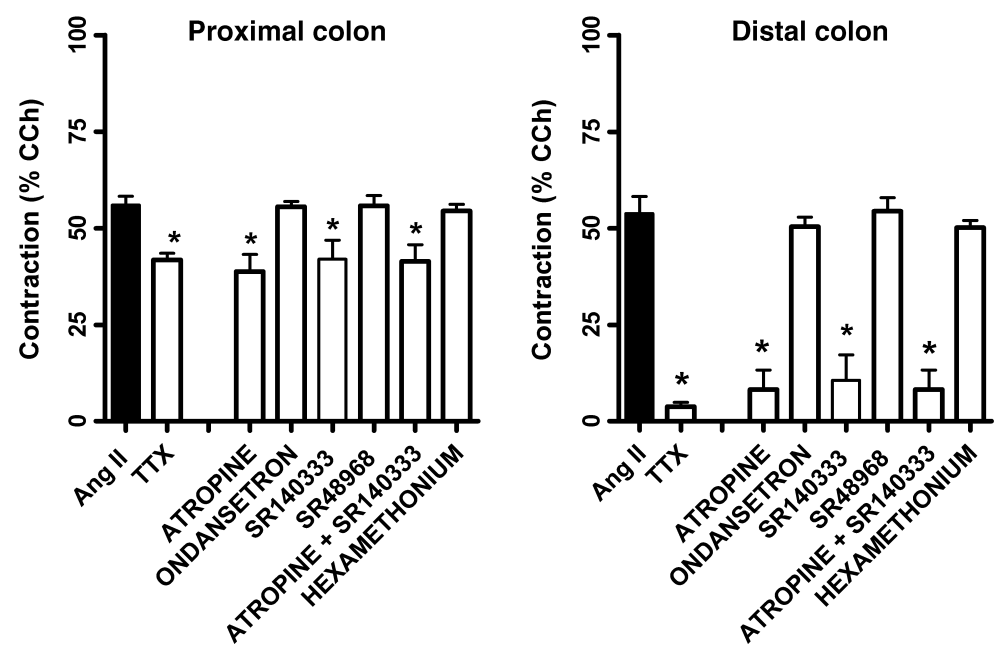

Figure 4 Histogram showing the effects of Ang II (1 nM) in mouse proximal and distal colon in the absence or in the presence of the $\mathrm{Na}^{+}$voltage-gated neural channel blocker, TTX $(1 \mu \mathrm{M}, n=5)$, the muscarinic receptor antagonist, atropine $(1 \mu \mathrm{M}, n=4)$, the $5-\mathrm{HT}_{3}$ receptor antagonist, ondansetron $(0.1 \mu \mathrm{M}, n=3)$, the $\mathrm{NK}_{1}$ receptor antagonist, SR140333 $(0.1 \mu \mathrm{M}, n=4)$, the $\mathrm{NK}_{2}$ receptor antagonist, SR48968 $(0.1 \mu \mathrm{M}, n=3)$, or the nicotinic receptor antagonist, hexamethonium $(30 \mu \mathrm{M}, n=3)$. Data are means \pm SEM and are expressed as percentage of the maximal effect induced by $10 \mu \mathrm{M} \mathrm{CCh}$. The graphed value for the control bar is the mean of the control data obtained before each treatment. $* P<0.05$ when compared to the respective own control condition.

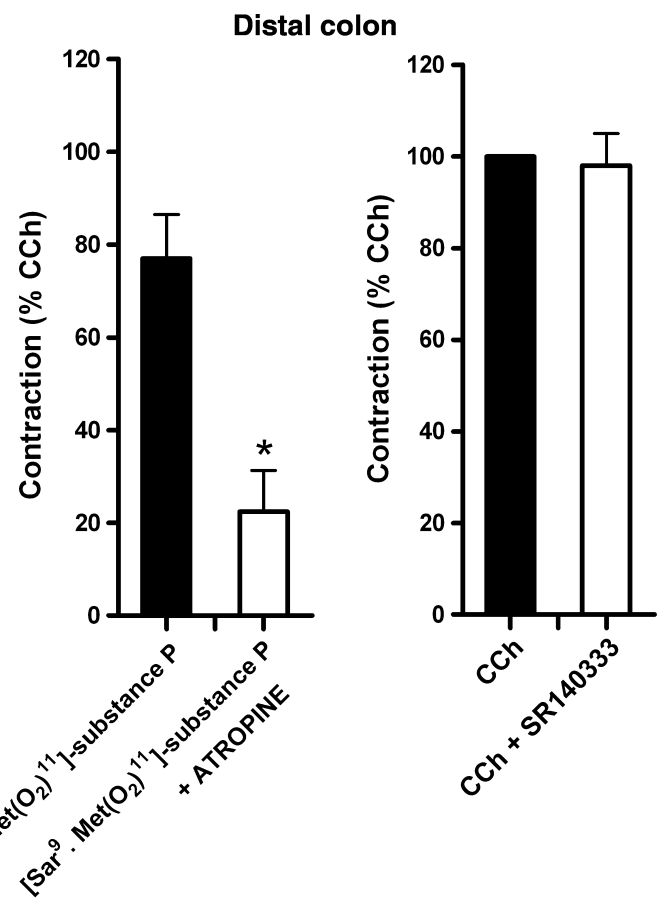

Figure 5 Histogram showing the effects of the $\mathrm{NK}_{1}$ receptor agonist $\left[\operatorname{Sar}^{9}, \operatorname{Met}\left(\mathrm{O}_{2}\right)^{11}\right]$-substance $\mathrm{P}(1 \mu \mathrm{M})$ in the absence or in the presence of the muscarinic receptor antagonist, atropine $(1 \mu \mathrm{M}, n=3)$, and of CCh $(10 \mu \mathrm{M})$ in the absence or in the presence of the $\mathrm{NK}_{1}$ receptor antagonist, SR140333 $(0.1 \mu \mathrm{M}, n=3)$ in mouse distal colon. Data are means \pm SEM and are expressed as percentage of the maximal effect induced by $10 \mu \mathrm{M}$ CCh. $* P<0.05$ when compared to the respective own control condition. model the longitudinal muscle of mouse colon. Our experiments showed a concentration-dependent contractile effect in response to Ang II in both proximal and distal colon. The concentration-response curve was significantly shifted to the right by the $\mathrm{AT}_{1}$ receptor antagonist losartan, indicating an $\mathrm{AT}_{1}$ receptormediated effect. The calculated $\mathrm{pA}_{2}$ values are in line with other reports (Schambye et al. 1994, De Godoy \& De Oliveira 2002). Moreover, Ang II effects were unaffected by the $\mathrm{AT}_{2}$ receptor antagonist, PD123319. These observations are in agreement with the previous studies in the human oesophageal muscle (Casselbrant et al. 2007), in the guinea-pig, rat and human small intestine (Hawcock \& Barnes 1993, Ewert et al. 2006, Spak et al. 2008) and in the guinea-pig stomach (Lu et al. 2011) where $\mathrm{AT}_{1}$ receptors are known to mediate mainly Ang II excitatory effects. Due to the results obtained by RT-PCR, it appears that the $\mathrm{AT}_{1}$ receptors subserving contractile effects belong to the subclass of $\mathrm{AT}_{1 \mathrm{~A}}$ receptors. It has been suggested that $\mathrm{AT}_{2}$ receptor activation counterbalances most effects that Ang II exerts through the $\mathrm{AT}_{1}$ receptors (Nouet \& Nahmias 2000, De Godoy \& De Oliveira 2002, Rattan et al. 2002, De Godoy et al. 2003) via the release of inhibitory autacoids (Siragy \& Carey 1999, Israel et al. 2000). In our preparations, we never observed inhibitory/relaxant effects of Ang II, although tissues were able to relax in response of isoproterenol. Because Ang II binds to its two receptor subtypes, $\mathrm{AT}_{1}$ and $\mathrm{AT}_{2}$, with a similar affinity, the tissue response is highly 


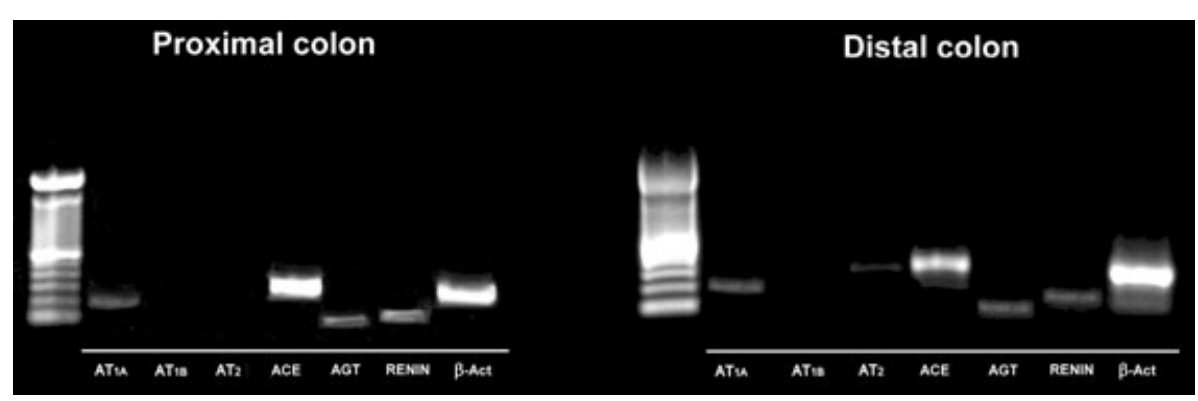

Figure 6 Expression of transcripts encoding the components of RAS, renin, angiotensinogen (AGT), angiotensin-converting enzyme (ACE), angiotensin receptors $\left(\mathrm{AT}_{1 \mathrm{~A}}, \mathrm{AT}_{1 \mathrm{~B}}, \mathrm{AT}_{2}\right)$ in proximal and distal colon preparation. $\beta$-Actin $(\beta$-Act) primer was used as a control for cDNA integrity. A 100-bp DNA ladder was used as marker.

dependent on the relative responsiveness of both receptors (Nouet \& Nahmias 2000). Therefore, when the $\mathrm{AT}_{1}$ subtype is inhibited and the $\mathrm{AT}_{2}$ receptor is free to interact with Ang II, the $\mathrm{AT}_{2}$-mediated effect becomes predominant (De Godoy \& De Oliveira 2002, Rattan et al. 2002, De Godoy et al. 2003). In our preparation, the $\mathrm{AT}_{2}$ receptor antagonist, $\mathrm{PD} 123319$, did not affect Ang II-induced contraction even when the $\mathrm{AT}_{1}$ subtype receptors are inhibited by losartan. Results from PCR analysis showed that in control condition, there is not a detectable expression of $\mathrm{AT}_{2}$ receptors in the proximal colon, whilst a low expression is evident in the distal colon. However, it should also be noted that $\mathrm{AT}_{2}$ receptor expression may vary according to tissue conditions, such as hypoxia or inflammation (Volpe et al. 2003, Smith \& Missailidis 2004). Further studies should address whether conditions may exist in which $\mathrm{AT}_{2}$ receptor expressions are increased in mouse colon and whether this is associated with an altered response to Ang II.

Tetrodotoxin partially antagonized the Ang II-induced responses in the proximal colon response suggesting that, in this region, $\mathrm{AT}_{1 \mathrm{~A}}$ receptors are localized both at pre-junctional level, where would acting modulating neurotransmitter release from the enteric nerves, and at post-junctional level, likely on the smooth muscle cells. Indeed, TTX abolished the effects of Ang II in distal colon, suggesting a prevalent localization of $\mathrm{AT}_{1 \mathrm{~A}}$ receptors at pre-junctional level in this region. Pre-junctional $\mathrm{AT}_{1}$ receptors, mediating Ang II effects, have been demonstrated in the guineapig small intestine (Hawcock \& Barnes 1993, Wang et al. 2005), whilst Ang II acts primarily through $\mathrm{AT}_{1}$ receptor located on the musculature in the isolated human and rat small intestine (Ewert et al. 2006, Spak et al. 2008) and human oesophagus (Casselbrant et al. 2007). In our preparations, the contractile response mediated by pre-junctional $\mathrm{AT}_{1 \mathrm{~A}}$ receptor activation was due to the involvement of cholinergic and tachykinergic pathways, because it was antagonized by atropine and by the selective antagonist of
$\mathrm{NK}_{1}$ receptor, SR140333. Either atropine or SR140333 reduces Ang II responses to a level not significantly different from that measured in the presence of TTX. Moreover, the observation that, when atropine and SR140333 were applied in combination, there were not any additive effects, indicates that acetylcholine and tachykinins, likely substance $\mathrm{P}$, are subsequently involved in the mediation of the indirect responses to Ang II in mouse colon. In particular, we may suggest that Ang II would induce release of substance $\mathrm{P}$ by enteric nerves, which acting on $\mathrm{NK}_{1}$ receptors, in turn, would induce release of acetylcholine, being the final contractile mediator, because, as already shown (Mule' et al. 2007, Matsumoto et al. 2009), the contraction induced by a selective $\mathrm{NK}_{1}$ receptor agonist was reduced by atropine, whilst SR140333 did not affect carbachol-induced muscular contraction. This conclusion differs from what observed in guinea-pig small intestine where Ang II responses are due to activation of angiotensin receptors located neuronally on both cholinergic and tachykinergic nerves (Hawcock \& Barnes 1993). Specie and tissue differences may account for this discrepancy. Moreover, because 5-HT through 5- $\mathrm{HT}_{3}$ receptor activation is involved in the regulation of intestinal contractility via modulation of neurotransmitter release either from cholinergic or noncholinergic neurones (Tuladhar et al. 2000, Chetty et al. 2006, Denes et al. 2009), we tested the possibility $5-\mathrm{HT}_{3}$ receptor activation could be involved in Ang II-induced contraction. Such a hypothesis can be discarded because Ang II effects were not modified by ondasetron, $5-\mathrm{HT}_{3}$ receptor antagonists. Indeed, in the neural circuit activated by Ang II, are not involved cholinergic interneurones as result by the lack of efficacy of hexamethonium treatment.

The observation that Ang II is able to affect intestinal contractility at a dose similar to the plasma concentration (about $0.01 \mathrm{~nm}$ ) detected in mouse under basal conditions (Cholewa \& Mattson 2005) indicates that angiotensin receptors in the mouse colon can be 
targeted by Ang II formed both at distance (endocrine action) and locally (paracrine action). The modulation of the colonic contractility and the consequent impact on intestinal transit can be one of the physiological mechanisms by which Ang II would control body fluid and electrolyte homoeostasis. We are aware that, in addition to the key mediator octapeptide Ang II, other AGT fragments have been shown to be biologically active, such as angiotensin ${ }^{1-7}$ and angiotensin III and $\mathrm{IV}$, and this will deserve attention.

In conclusion, the presence in the murine colon of the components of RAS suggests that Ang II is also locally generated to control mouse colon motility. In particular, Ang II positively modulates the spontaneous contractile activity via activation of post-junctional and pre-junctional $\mathrm{AT}_{1 \mathrm{~A}}$ receptors, the latter located on the enteric nerves and modulating the release of tachykinins and acetylcholine. Tachykinergic neurones and cholinergic neurones are sequentially recruited by Ang II to induce muscular contraction.

\section{Conflict of interest}

None.

This work was supported by a grant from Ministero dell'Università e della Ricerca Scientifica - Italy.

\section{References}

Baldassano, S., Zizzo, M.G., Serio, R. \& Mulè, F. 2009. Interaction between cannabinoid $\mathrm{CB}_{1}$ receptors and endogenous ATP in the control of spontaneous mechanical activity in mouse ileum. Br J Pharmacol 158, 243-251.

Casselbrant, A., Edebo, A., Wennerblom, J., Lonroth, H., Helander, H.F., Vieth, M., Lundell, L. \& Fandriks, L. 2007. Actions by angiotensin II on esophageal contractility in humans. Gastroenterology 132, 249-260.

Chetty, N., Irving, H.R. \& Coupar, I.M. 2006. Activation of 5-HT3 receptors in the rat and mouse intestinal tract: a comparative study. Br J Pharmacol 148, 1012-1021.

Cholewa, B.C. \& Mattson, D.L. 2005. Influence of elevated renin substrate on angiotensin II and arterial blood pressure in conscious mice. Exp Physiol 90, 607-612.

De Gasparo, M., Catt, K.J., Inagami, T., Wright, J.W. \& Unger, T. 2000. International union of pharmacology. XXIII. The angiotensin II receptors. Pharmacol Rev 52, 415-472.

De Godoy, M.A. \& De Oliveira, A.M. 2002. Cross-talk between $\mathrm{AT}(1)$ and $\mathrm{AT}(2)$ angiotensin receptors in rat anococcygeus smooth muscle. J Pharmacol Exp Ther 303, 333-339.

De Godoy, M.A., Accorsi-Mendonca, D. \& de Oliveira, A.M. 2003. Inhibitory effects of atropine and hexamethonium on the angiotensin II-induced contractions of rat anococcygeus smooth muscles. Naunyn Schmiedebergs Arch Pharmacol 367, 176-182.

Denes, V., Wilhelm, M., Nemeth, A. \& Gabriel, R. 2009. Interactions of serotoninergic, cholinergic, and tachykinin- containing nerve elements in the rabbit small intestine. Anat Rec (Hoboken) 292, 1548-1558.

Ewert, S., Spak, E., Olbers, T., Johnsson, E., Edebo, A. \& Fandriks, L. 2006. Angiotensin II induced contraction of rat and human small intestinal wall musculature in vitro. Acta Physiol (Oxf) 188, 33-40.

Fändriks, L. 2010. The angiotensin II type 2 receptor and the gastrointestinal tract. J Renin Angiotensin Aldosterone Syst 11, 43-48.

Fändriks, L. 2011. The renin-angiotensin system and the gastrointestinal mucosa. Acta Physiol 201, 157-167.

Fyhrquist, F. \& Saijonmaa, O. 2008. Renin-angiotensin system revisited. J Intern Med 264, 224-236.

Garg, M., Angus, P.W., Burrell, L.M., Herath, C., Gibson, P.R. \& Lubel, J.S. 2012. Review article: the pathophysiological roles of the renin-angiotensin system in the gastrointestinal tract. Aliment Pharmacol Ther 35, 414-428.

Hawcock, A.B. \& Barnes, J.C. 1993. Pharmacological characterization of the contractile responses to angiotensin analogues in guinea-pig isolated longitudinal muscle of small intestine. Br J Pharmacol 108, 1150-1155.

Israel, A., Cierco, M. \& Sosa, B. 2000. Angiotensin AT(2) receptors mediate vasodepressor response to footshock in rats. Role of kinins, nitric oxide and prostaglandins. Eur J Pharmacol 394, 103-108.

Jackson, E.K.. 2001 Renin and angiotensin. In: L.S. Goodman \& A. Gilman (eds) The pharmacological basis of therapeutics, 10th edn, pp. 809-841. McGraw-Hill, New York.

Johren, O., Golsch, C., Dendorfer, A., Qadri, F., Hauser, W. \& Dominiak, P. 2003. Differential expression of AT1 receptors in the pituitary and adrenal gland of SHR and WKY. Hypertension 41, 984-990.

Lu, H.L., Wang, Z.Y., Huang, X., Han, Y.F., Wu, Y.S., Guo, X., Kim, Y.C. \& Xu, W.X. 2011. Excitatory regulation of angiotensin II on gastric motility and its mechanism in guinea pig. Regul Pept 167, 170-176.

Matsumoto, K., Kurosawa, E., Terui, H., Hosoya, T., Tashima, K., Murayama, T., Priestley, J.V. \& Horie, S. 2009. Localization of TRPV1 and contractile effect of capsaicin in mouse large intestine: high abundance and sensitivity in rectum and distal colon. Am J Physiol Gastrointest Liver Physiol 297, G348-360.

Mule', F., Amato, A. \& Serio, R. 2007. Role for NK(1) and $\mathrm{NK}(2)$ receptors in the motor activity in mouse colon. Eur J Pharmacol 570, 196-202.

Nouet, S. \& Nahmias, C. 2000. Signal transduction from the angiotensin II AT2 receptor. Trends Endocrinol Metab 11, $1-6$.

Nylander, O. 2011. The impact of cyclooxygenase inhibition on duodenal motility and mucosal alkaline secretion in anaesthetized rats. Acta Physiol 201, 179-192.

Paul, M., Poyan, M.A. \& Kreutz, R. 2006. Physiology of local renin-angiotensin systems. Physiol Rev 86, 747803.

Persson, P.B. \& Henriksson, J. 2011. Good publishing practice in physiology. Acta Physiol (Oxf) 203, 403-407.

Rattan, S., Fan, Y.P. \& Puri, R.N. 2002. Comparison of Angiotensin II (Ang II) effects in the internal anal sphincter 
(IAS) and lower esophageal sphincter smooth muscles. Life Sci 70, 2147-2164.

Schambye, H.T., Hjorth, S.A., Bergsma, D.J., Sathe, G. \& Schwartz, T.W. 1994. Differentiation between binding sites for angiotensin II and nonpeptide antagonists on the angiotensin II type 1 receptors. Proc Natl Acad Sci USA 91, 7046-7050.

Siragy, H.M. \& Carey, R.M. 1999. Protective role of the angiotensin AT2 receptor in a renal wrap hypertension model. Hypertension 33, 1237-1242.

Smith, G.R. \& Missailidis, S. 2004. Cancer, inflammation and the AT1 and AT2 receptors. J Inflamm (Lond) 1, 3.

Spak, E., Casselbrant, A., Olbers, T., Lonroth, H. \& Fandriks, L. 2008. Angiotensin II-induced contractions in human jejunal wall musculature in vitro. Acta Physiol (Oxf) 193, 181-190.

Tuladhar, B.R., Womack, M.D. \& Naylor, R.J. 2000. Pharmacological characterization of the 5-HT receptor- mediated contraction in the mouse isolated ileum. $\mathrm{Br}$ J Pharmacol 131, 1716-1722.

Volpe, M., Musumeci, B., De, P.P., Savoia, C. \& Morganti, A. 2003. Angiotensin II AT2 receptor subtype: an uprising frontier in cardiovascular disease? J Hypertens 21, 1429-1443.

Wang, G.D., Wang, X.Y., Hu, H.Z., Fang, X.C., Liu, S., Gao, N., Xia, Y. \& Wood, J.D. 2005. Angiotensin receptors and actions in guinea pig enteric nervous system. Am J Physiol Gastrointest Liver Physiol 289, G614G626.

Zizzo, M.G., Mulè, F. \& Serio, R. 2006. Inhibitory responses to exogenous adenosine in murine proximal and distal colon. Br J Pharmacol 148, 956-963.

Zizzo, M.G., Mastropaolo, M., Lentini, L., Mulè, F. \& Serio, R. 2011. Adenosine negatively regulates duodenal motility in mice: role of $\mathrm{A}(1)$ and $\mathrm{A}(2 \mathrm{~A})$ receptors. $\mathrm{Br}$ J Pharmacol 164, 1580-1589. 